\title{
LUCIAN BLAGA ȘI B. FUNDOIANU - IPOSTAZE ANTAGONICE ÎN CADRUL „EXPRESIONISMULUI ROMÂNESC”
}

\section{IONUCU POP}

\section{Universitatea Babeș-Bolyai, Cluj-Napoca}

Abstract: The goal of the following paper is to shed more light unto the similarities and the particularities that the works of Lucian Blaga and B. Fundoianu reveal in relation to Expressionism, a current often mentioned in order to catherogirse the two poets. Even though one cannot put the finger on a legitimate Expressionist poetic movement in Romanian culture without a certain ammount of exaggeration, the poetry of the aforementioned figures is undeniably compatible with the current originated from Germany. As I will try to prove, Lucian Blaga and B. Fundoianu can be seen as antagonistic instances in this context, but ultimately revealing a shared expressionist substance upon which the most divergent attitudes are bestowed.

Keywords: Expressionism, antagonism, territoriality, metaphysics, the apocalyptic.

Lucian Blaga și B. Fundoianu pot fi considerați drept principalii reprezentanți ai expresionismului în poezia noastră, atât prin proporția operei poetice care poate fi încadrată în liniile curentului de origine germană, cât și prin particularitățile pe care cei doi le nuanțează în interiorul acestei mișcări din prima jumătate a secolului trecut. $\mathrm{O}$ astfel de informație nu ar trebui să surprindă, deși, studiul are în vedere două cazuri diferite în ceea ce privește conștiința clasării eului creator în cadrul expresionismului. Iar acesta nu este singurul plan în care Blaga și B. Fundoianu se plasează la poli diferiți.

Deși în critica de specialitate există cercetări ample asupra operei lui B. Fundoianu (vezi Mircea Martin, Introducere în opera lui B. Fundoianu), respectiv a lui Blaga (Ion Pop Lucian Blaga - Universul liric), nu există niciun studiu care să pună în valoare spațiul comun și divergențele dintre 
poeții vizați în ceea ce privește expresionismul.

Dintre curentele moderniste, civilizația mecanicistă a găsit unul din cei mai interesanți și productivi oponenți în curentul expresionist. In Germania, industrializarea accelerată, aproape abruptă, inegală de la sfârșitul secolului al XIX-lea dă naștere primei generații de expresioniști, crescută într-o lume cu adevărat derutantă. Atât progresul tehnicoștiințific de nestăvilit cât și Primul Război Mondial îl găsesc pe individul cu afinități expresioniste într-o poziție dificilă: între o uriașă nevoie de schimbare, dar și o atitudine conservatoare, ba chiar regresivă, cât mai departe de idealurile pozitiviste.

După cum demonstrează Ov. S. Crohmălniceanu, curentul pătrunde în orizontul nostru prin mediul cultural german al Transilvaniei și Bucovinei, care reușește să se polarizeze într-o oarecare măsură la "Gândirea” și „Contimporanul”. Expresionismul se va acomoda cu acele aspecte cu care prezintă compatibilitate în contextul solului nostru cultural. Se explică astfel de ce latura activistă a expresionismului nu s-a înrădăcinat. „Foamea de schimbări, explozive, revoluționare, utopismul și umanitarismul frenetic lipsesc aproape complet din tendințele expresioniste românești. Procesul - încă foarte slab - de omogenizare socială a lumii noastre citadine a făcut ca «stihia» mulțimii să nu obsedeze conștiința intelectualității” (Crohmălniceanu, 1971, 236). În schimb, refugiul în primitivism, cosmicitate, mistică naturistă și scufundarea în mit își găsesc sol roditor, realitate concretă la care să adere, care să ofere compatibilitate în lumea satului românesc.

Este important de menționat faptul că, în conștiința literară românească, expresionismul pătrunde abia după Primul Război Mondial. „Mișcarea apăruse în Germania cu aproximativ un deceniu înainte, dar anii 1918-1920 constituie momentul când ea își atinge punctul culminant și capătă o rezonanță mondială.” (Crohmălniceanu, 1971, 13). Anii războiului constituie și momentul în care se scriu majoritatea poemelor din Priveliști și Poemele luminii.

In ceea ce privește principalii vehiculatori ai curentului în cultura noastră, („Gândirea” și „Contimporanul”), programatic, revistele (dar și poeții vizați) stau în dreptul celor două principale orientări în interiorul expresionismului: cea regresivă în cazul revistei lui Crainic și cea progresivă in programul creatorilor cu afinități constructiviste. In realitate orientarea progresivă (paradoxal, ilustrată cel mai fidel de către un poet de la „Gândirea”, Aron Cotruş), cedează la noi în fața laturii regresive, reprezentată de întoarcerea spre primitivism, recuperarea mitului, abstractizare si elementarizare în aceste 
cadre precum și de viziunea stibială și cosmică.

Fondane ne informează în prefața lui pentru volumul Priveliști, Câteva cuvinte pădurețe că: „Poezia aceasta s-a născut în 1917, pe vremea războiului într-o Moldovă mică cât o nucă, într-o febră de creștere, de distrugere. Nimic din ceea ce constituie materia primă a acestui lirism nu mai exista în realitate" (Fundoianu, 2011, 105). Din această prefață se pot extrage importante trăsături ale esteticii expresionismului: opoziția față de carnagiul mondial și mecanicism prin potențarea forței naturii, a vitalității; deformarea realității materiale prin revelarea unui fond metafizic ineglijabil - în continuarea, dar mai ales, împotriva (în cazul lui Fundoianu) sensibilității spirituale a eului poetic, „exagerarea” expresionistă etc.: „Natura, în poemele lui, apărea ridicată la o potență mai mare ca imaginea ei normală, ca o supapă prin zidul de foc" (Fundoianu, 2011, 106). Adevărul este că, neintenționat, Fondane mărturisește în prefaţă un crez expresionist având impresia, de fapt, că acesta contribuie la constructivismul românesc, de unde filonul critic al plasării creației sale în modernitatea extremă a avangardelor. Dincolo de prefață, opera însăși a lui B. Fundoianu infirmă ipoteza constructivistă. „Priveliştile ne aduc în față un peisaj nu mai puțin inventat, stilizat, dar nu în sensul îndulcirii lui compensatoare, ci al unei desfigurări neliniștitoare, amenințătoare.” (Fundoianu, 2011, 106), spune Mircea Martin în Poezia lui B. Fundoianu, o poezie care „stie” mai mult decât poetul, prefața volumului citat. In momentul scrierii poeziilor, Fundoianu era preocupat de afirmarea proprie prin diferențiere, în special de sfidarea mentalului sămănătorist - aspect în care a fost precedat cronologic de Ion Vinea (Manolescu, 1987, 208). Nu ar fi singura dată, în contextul epocii, când astfel de legături neașteptate se revelează între expresionism şi constructivism. Ba chiar pe acest liant se creează „punți” între „Gândirea” și „Contimporanul”. Când Lucian Blaga mărturisea că arta modernă ar trebui să tindă către anonimatul marilor epoci de creație colectivă, Marcel Iancu constată cu uimire: „Dar e exact credința noastră, a constructiviștilor!” (Aderca, 1967, 36). În cazul lui Blaga, relaționarea cu expresionismul nu poate fi pusă la îndoială. Acesta este, în conștiința critică, principalul reprezentant al literaturii noastre în opera căruia apar reflexe, uneori deosebit de intense, ale curentului german. Pe lângă operă este mereu luată în considerare și „contribuția teoretică, de mare însemnătate, a poetului: în articolele din "Gândirea», în Filosofia stilului, în Fețele unui veac, în Ferestre colorate - toate scrise în deceniul al treilea - Blaga a operat distincții teoretice subtile, relevând fundamentele unei orientări spirituale și stilistice asupra căreia, și mai 
târziu, va reveni câteodată” (Grigorescu, 1980, 395).

Latura metafizică a expresionismului este unul din factorii care a făcut posibilă compatibilitatea curentului german cu spațiul cultural românesc. Expresionismul, prin această predispoziție către transcendent, răspunde „strădaniei principale a Gândirii” de a deschide o zare metafizică tradiționalismului și, în același timp, de a împinge diferitele tendințe ale spiritualismului și iraționalismului modern către o expresie autohtonă” (Crohmălniceanu, 1971, 53). Se va observa că problematica metafizică este o punte necesară pentru compararea lirismului lui Blaga cu cel al lui Fundoianu.

Factorii culturali și etnici importanți și evidenți în această problematică ajută atât la explicarea unor diferențe majore de orientări, imaginare, atitudini, cât și la formarea unor dihotomii care să ne ajute analiza pe parcurs. Acesti factori includ fondurile native si elementele de substrat cultural din formațiunea celor doi. In primul rând, este vorba despre fondul nativ iudaic in cazul lui Fundoianu s, cel autohton de partea lui Blaga. In ceea ce privește elementele de substrat, deosebirile stau în preferință. Blaga diferențiază influentele culturale modelatoare de cele catalitice. Cultura franceză, în dreptul căreia se ațintesc privirile lui Fundoianu, este exemplu pentru prima categorie. Exprimat plastic, cultura franceză se oferă drept model și $\hat{\imath} i$ spune celui care vine în contact cu ea ,fii cum sunt eu!". Ea cultivă, în viziunea lui Blaga, ca efect, tipicul, legea, echilibrul, generalul, măsura. Cultura germană, în vecinătatea căreia se plasează preferințele lui Blaga, prezintă un caracter obsedat de individual și particular. Efectul catalitic este de "fii tu insuți!": „Influența spiritului german asupra celorlalte popoare a avut [...] mai puțin caracterul unui model de imitat, cât caracterul unui apel la propria fire, la propriul duh etnic al acestor popoare" (Blaga, 2018, 307-308). Putem adăuga ecuației așadar, drept componente de strat, influențele culturii franceze și culturii germane. Firește că o tranșare absolută ar fi o exagerare, iar, în realitate, elementul german, catalitic se suprapune amândurora dintre poeți (vezi influența lui Nietzsche asupra lui Fundoianu). In ceea ce privește compatibilitatea cu expresionismul, curent de factură germanică, afinitățile prezente la Fundoianu față de spațiul francez nu ridică mari probleme, în special datorită interesului său pentru acea suprafață care este potențtoare pentru poetica expresionistă, sau care este pe placul expresioniștilor, adică descendența rimbaldiană. In aceste reacții culturale, etnice, stă de fapt o posibilă cheie de interpretare și schițare a celor două poetici și trasee biobibliografice în general. Distingem astfel două tipuri de atitudine care $\hat{\imath} i$ plasează pe poeții noștri într-un aparent antagonism. Fondul iudaic al lui 
Fundoianu, influențat de modelul francez va rezulta într-un exod înspre cultura modelatoare. In timp ce fondul românesc al lui Blaga asupra căruia se aplică influența catalizatoare a culturii germane, rezultă într-o adâncire in arhetipurile culturii românești. Prin urmare, atunci când eul liric blagian este separat fizic de terenul familiar orizontului său inconștient sau spațiului său matrice, acesta va revela ceea ce noi numim o atitudine odiseică, opusă exodicului. Avem ca exemplu poezia Soare iberic, unde eul liric resimte un dor de casă absolutizat conform esteticii expresioniste: „O clipă mă amăgesc cu Oceanul ce se vede-n zare,/ dar umbră nici apa nu are/ să-mi învelească inima bolnavă. Să-mi învelească inima bolnavă,/ mi-ar trebui de-aiurea dezmierdare,/multa-nrourata slavă./ A Valahiei deasă, largă,/reavănă dumbravă". Blaga tânjește după imaginarul de acasă, ca Odiseu, iar Fundoianu după cel dinafară, într-un spirit emigrant - exodic. În această secționare a celor două poetici, tânjirea după un alt teritoriu, prielnic sufletului, este comună, însă orientările sunt opuse. Putem argumenta acest aspect al liricii celor doi ca fiind compatibil cu poetica expresionistă prin ipostazele pe care cei doi le dau inaderenței. După cum s-a văzut în poemul anterior, la Blaga inima este bolnavă. La Fundoianu, în Herța, $I V$ existența de acasă este asociată cu o convalescență: „E-așa de lungă vremea de când nu mai e azi/ și stearpă și molâie ca o convalescență./ Aștepți în toată seara aceeași diligență/ care debarcă aceiași ovrei care se întorc./ In case, știu vapoare ce pleacă spre New Yorkl și bancuri unde-oceanul a descărcat ciolane.” Exagerarea inaderenței la nivel de traumă a întregului suflet convine expresionismului. Aceeași privire visătoare înspre un spațiu exterior celui natal se întrevede și la finalul ciclului Provincie. „Ai vrea, din vechi balcoane, să le arunci seminți./ Când orele bătrâne aruncă-n turnuri noapte,/ uzi de tăcerea lungă, de sânge și de lapte,/ par niște urne pentru cenușile de morți/ Steaguri de pace, uite-i, ca și-n trecut, în porți/ șiașa cum stau, de parcă nu-i învechește timpu -l - Veneție, porumbii au sufletul tău simplu." Acest poem se plasează într-un evident contrast cu restul ciclului, deoarece realitatea vizată este una distantă, profund nobilă și pe placul aristocratului din Fundoianu. Nimic din târgul din Priveliști nu se regăsește în Veneția, decât timbrul poetului, a cărui atitudine se schimbă radical, se apolinizează.

Aceste atitudini care-i apropie și, finalmente, separă pe acești doi expresioniști ne pun în legătură cu teritorialitatea expresionistă în lirica românească. Opozițiile care se manifestă în această problematică a curentului sunt cele precum sat-oraş, suflet-spirit, cultură-civilizație, natură-așezare umană, mit-istorie etc. De regulă primul element al fiecăreia 
dintre dihotomiile anterioare este cel favorizat de poeții expresioniști.

În cazul lui Blaga și Fundoianu am constatat puncte comune care țin de acest fond expresionist comun; Fundoianu desconsideră târgul drept un tip de așezare instabilă, nedemnă, în timp ce Blaga pedepsește oraşul pentru viciile sale ce corup până și transcendentul. Mircea Martin folosește pentru o parte a poeziei lui Fundoianu sintagma de lirism al inaderenței. Această sintagmă poate fi folosită pentru o parte a poeziei lui Blaga, mai exact pentru poezia orașului. Toposul urban în lirica blagiană este din start sortit prăbușirii. În opoziție cu toposul satului, care menține o legătură strânsă cu miticul, care se înrâurește cu natura și cu veșnicul și care oferă posibilitatea schimbului de taine cu originea și cu cosmicul, orașul constituie materializarea abaterii, așezare a căderii omului, casa faptei. Tot ce se petrece în spațiul cetății poartă o urmă de degradare, iar înfăptuirea în asemenea spațiu este o sfidare a cosmicului și a armoniei. Cu toate acestea, oraşul nu e dezbrăcat de transcendență, însă această transcendență este de ordin malefic. Locuitorul oraşului, în mândria sa și în abaterea sa, nu mai știe să tălmăcească natura sau divinul. În poezia oraşului, eul blagian este deziluzionat. El denunță cu scepticism făgăduințele civilizației: „f̆găduitu-ni-s-au fabrici lângă râuri sfinte,/rugăciuni de clopote să ni se pară, fapta mânilor între motoare" (Făgăduinți în flăcări). Durerea orașului blagian este de proporții biblice: „suferim cu crinii-n gură/silnicia din Egipet". Tot cu ecou biblic în lirica blagiană, publicat în "Gândirea” în 15 mai 1925, poemul Lot reprezintă una dintre cele mai puternice mustrări aduse orașului în lirica românească. În expresionismul german, orașul este mediu al uciderii și al înstrăinării. În contact cu Blaga, această latură a expresionismului capătă aură mitică: „Am văzut femei arzându-și sămânța în flăcări/ rostul lor azvârlit între două eternități ca o batjocură,/ sânii lor fructe coapte fără de lapte,/ răsuflarea lor omorând albine si ierburi./ Am văzut oaspeți străvezii pe țărmul sângelui:/ copii cari vor să se nască și nu sunt primițì". Soarta damnată a orașului în lirica blagiană este un simptom al separării de Marele Tot. „Tăgăduirea obârșiei cerești a pământului e încă o formă a alienării omului căzut în timp" (Mariş, 1996, 93). Locuitorii cetăților în gesturile lor oarbe de desacralizare și tulburare a adâncurilor se plasează sub zodia tristeții metafizice. Poezia Veac din volumul Lauda somnului continuă damnarea orașului. Spațiu al viciului și al desacralizării, orașul reușește să corupă forța transcendentală: „Arhanghelii sosiți să pedepsească orașul/ s-au rătăcit prin baruri cu pene arse". În universul blagian de sub tristețea metafizică orașul este un topos care are nevoie de justiție de ordin divin în imanență din cauza păcatelor 
sale. Însă degradarea ontologică este atât de puternică, încât cerescul (la fel ca în Paradis in destrămare) se descompune în contact cu Boala. În Veac, ultima strofă răstoarnă tonul, imaginarul și miza poemului: „Dar sus, la o mie de metri-nălțime, spre răsărit/ stelele își spun povești prin cetini de brazi/ și-n miez de noapte, râtul mistreților/ deschide izvoarele.” "Singura perspectivă salvatoare" (Pop, 1999, 102) se află în geografia miticului, iar o asemenea retragere constituie un gest de factură expresionistă.

La Fundoianu, târgul este cel ce devine spațiul vinovat. Stadiul periferic al târgului îl prezintă drept zonă șubredă și necoagulată, un kitsch în mijlocul naturii, o ruinare atât a peisajului cât și a antipeisajului. „Peste târgul lui Fundoianu cade o ploaie galițiană, pustiitoare, nesfârșită. Decorul este sordid, agonic, bacovian” (Martin, 1984, 190) : „și plouă, plouă.../ gâștele sub punți/ au leșinat în toamna albă, lângă/ sufletul care ar voi să plângă." (Provincie, $I$ ). Un astfel de spațiu este sortit înfrângerii mai târziu în același ciclu. Tocmai din cauza păcatului de a se opune unei forțe mult mai mari, târgul va fi supus mustrărilor poetului și asediului naturii. Considerăm poemul ProvincieI, III cel mai reprezentativ pentru teritorialitatea expresionistă în lirica lui Fundoianu: /,Târg ticălos, cu ulițe și străzi/sparte de ploi, de vite și de care -laici, în câmp, pe vremuri, creștea soare,/aici creștea ovăz." Surprinzător, Fundoianu este solidar cu natura, reușind prin poem un efect dublu. El întinde o capcană de atitudine sămănătoristă (prin alegerea imaginarului rural) însă, în același timp, o dislocă prin tehnici neîntâlnite până la el în lirica românească. Dacă mentalul sămănătorist ar deplânge, la fel ca și expresioniștii din primul val, invazia civilizației, a străzilor, Fundoianu, tot printr-un gest expresionist, răstoarnă situația, surprinzând explozia de neoprit a naturii, care supune spațiul nedorit al târgului cu o siguranță cosmică: „Pământul iese-n față, se strecoară,/ crește-n spărturi, se cațără prin zid,/ și gras, sentinde, pentru-a doua oară,/ peste asfaltul biruit." Omul, în lirica lui Fundoianu, își păstrează ipostaza animală și este îngăduit într-un univers cu puteri mult mai mari pentru înțelegere. "Și oameni după garduri se furişăa/bivolii grei când vin de la păscut/calcă-n asfalt, se culcă sau se pișă,/ cu coarnele-n văzduh ca la-nceput.” Antitradiționalismul lui Fundoianu este deschizător de tărâmuri în lirica românească. Deși este un antipeisaj, poezia aceasta poate funcționa și sub forma unei priveliști de una singură, fără să avem lentila inaderenței atașată. Se explică astfel dificultatea criticilor din trecut de a-l încadra. După asediul pluvial, bacovian de la începutul seriei Provincie, Fundoianu îşi impune propriul timbru cântând asediul vegetal. Renașterea explozivă este locul în care poetul nostru se 
desparte de Bacovia. Reinstaurarea naturii prin forță de nestăvilit este o imagine pe placul expresioniștilor. „Pe sticle sparte se prăjesc șopârle,/ din pomi greoaie fructe cad în vânt-/ de parcă-o mână de văzduh azvârle/ semințe noului pământ."

Cert este că, față de târgul provincial, Fundoianu folosește acel lirism al inaderenței. Târgul este șubred, neimpunător, bacovian, iar orașul la Blaga este casa faptei, căderea omului. Aceste asocieri convin esteticii expresioniste, urbanul și cvasi-urbanul sunt conotate negativ în opoziție cu satul sau natura, dar poeții noștri nu se rezumă la simple opoziții. Blaga conferă și oraşului aură transcendentă, numai că aceasta se plasează sub zodia maleficului, chemând apocalipticul, o altă categorie esențială a esteticii expresioniste.

„Se crede că sunt cu putință numai două feluri de a concepe lucrurile: logicul și nelogicul. Eu cred într-o a treia posibilitate: apocalipticul. Realitatea e de natură apocaliptică, adică: realitaea se desfășoară în revelații de-o absurditate divină, în care fulgerător ghicessti un înțeles superior pe care nu-l poți prinde" (Blaga, 1973, 289-290). Înrudit sufletește cu omul romantic, expresionistul simte apăsător prezența tragicului în propriul destin. $\mathrm{O}$ teamă de vid și de sterp alungă expresionistul înspre o goană metafizică, la nivel colectiv luând forma unui adevărat sentiment al apocalipsei care pândește. „Mitul scientismului se dovedise iluzoriu pe fondul de contradicții ce perpetuau niște relații socio-politice perimate. Scriitorii, artiștii plastici, filosofii presimțeau dislocări iminente ce le va aduce războiul apropiat.” (Mariş, 1996, 7). Pe plan istoric, temerile și presimţirile expresioniștilor aveau să își găsească materialitate în Primul Război Mondial, care, prin exagerare, devine sinonim cu apocalipsa.

Între apocalipticul lui Fundoianu și cel al lui Blaga înregistrăm următoarele diferențe. Dacă la Blaga apocalipticul se manifestă vertical pe scara transcendenței, la Fundoianu apocalipticul este orizontal. Această diferență se poate vedea din cele două tipuri de apocaliptic pe care le-am identificat pentru fiecare dintre cei doi. La Fundoianu vorbeam de un apocalips teluric, în care pământul erupe în mișcare seismică și acoperă cu bulgări de întuneric omul. Poemul Ce simplu... este ilustrativ pentru aceste tulburări. Fauna trădează neliniștea cosmică: „Cirezi halucinante mugesc pe după vie”. În cheie apocaliptică avem o figură ambiguă și din punct de vedere metafizic care predică: „Un popă - poate Naiba - cu mintea spre mălai, peste sicriu, cu brațul întins, blagoslovește”. Finalul poemului este lipsit de orice marcă afectivă, spaimă sau groază, reușind intensificarea tragismului: „Din curba lui, pământul s-a-ntins, se umflă, 
crește,/ și cheamă către dânsul oamenii de noroi./ Și oamenii se culcă cu sufletu-n noroi,/ îl scuipă, îl sărută, îl blastămă, îl iartă -/ și bulgării de noapte se prăbușesc pe moartă.”. Tot pe orizontală la scara transcendenței, Fundoianu naturalizează apocalipticul, oferindu-i o naștere și desfășurare integrabile într-un ciclu natural. În această formă, apocalipticul devine agrest, ciclurile erotice ilustrând această ipostază. Mircea Martin, continuând o observație a lui M. Petroveanu, leagă iminența morții de trăirea plenară, care se realizează atât de rar în decursul Priveliştilor: „Ne putem întreba, în continuare, dacă plenitudinea însăși apropie ideea sfârșitului ori dacă, dimpotrivă, apropierea sfârșitului face să se realizeze plenitudinea” (Martin, 1984, 178). Plăcerea și moartea sunt inseparabile în poezia lui Fundoianu, de aceea apocalipticul cere o intensitate pe care numai eroticele le pot oferi. Apocalipsul agrest ia aici formele ecloziunii, ale coacerii până la erupție. Avem parte de o adevărată mișcarea circulară thanatico-erotică în poeziile lui Fundoianu. Eroticul își încarcă argumentele prin plasarea situației în iminent apocaliptic, iar moartea este necesară pentru a da viață: ,T,i-aș spune: seara asta e ultima din toamnă,/ și toamna asta, poate, e cel din urmă an,/ e cel din urmă soare și cea din urmă poamă; și s-ar putea, femeie, să fiu un Canaan,/ urât și sterp, când încă ți-s țâțele cu lapte?” (Mărior,II).

La Blaga am identificat apocalipticul celest, cauzat de subnutrirea transcendentă, de lipsa posibilității de comunicare cu adevărul divin, cu Dumnezeu, suferit de orânduirea cerească și de mecanismul cosmic. În volumele de maturitate, apocalipticul la Blaga se manifestă ca efect al tristeții metafizice. În această etapă, sfârșitul acționează pe planuri multiple: în dihotomia tradițional-expresionistă sat-oraş, dar mai ales în scara ontologic-metafizic. Lamentația trecerii și sentimentul desacralizării lumii ating în poetica măcinată de neliniștea lui Blaga, în momente de deznădejde covârșitoare, punctul apocaliptic. Transcendentul este răpus de boală. Sacralul este erodat, contaminat de lumesc. La fel cum în pustie, Ioan lamenta pierderea lui Dumnezeu, acest paradis este zăvorât comunicării divine. „Portarul înaripat mai ține întins/un cotor de spadă fără de flăcări./Nu se luptă cu nimeni,/dar se simte învins.” (Paradis în destrămare). Precum în gnosticism sau în neoplatonism, cu cât divinitatea supremă este mai aproape, cu atât este mai posibilă comunicarea, urcarea, iar emanațiile acesteia mențin în grație realitățile atinse. În Paradis în destrămare din volumul Lauda somnului, emanațiile divine nu mai ating Paradisul însuși. Coborând de la celest la teluric, în poezia lui Blaga apocalipticul este atras mai ales de spațiul orașului. Poezii ca Făgăduinți în 
flăcări, Lot, dar mai ales Semne sunt reprezentative pentru acest apocalips urban, consecință a înstrăinării omului de natură, a îndepărtării de Origo, a ieșirii din geografia mitului și abaterii de la poveste.

Fundoianu, spre deosebire de Blaga, nu prezintă deloc dramatic apocalipticul, ci cu o indiferență apropiată de plictiseală, ba chiar îl observăm pe poet chemând Catastrofa pentru a altera monotonia: „te-aștept să vii, trompetă de spaimă, Catastrofă,/ sărut urcând în ochii oceanelor, prelung." (Paradă). Lipsa de importanță a omului precum și evitarea identificării au însă efectul întețirii tragismului, citite în strat profund, versurile lui Fundoianu sunt cu adevărat neliniștitoare. La Blaga apocalipticul este dramatic la propriu, acesta oferind chiar un poem de factură dramatică pentru ilustrarea sa (propriu-zis, apocalipticul își face apariția în lirica blagiană la sfârșitul volumului Pașii profetului în poemul dramatic Pustnicul). Exclamații precum „vai mie, vai ție” nu o să fie nicăieri de găsit într-o poetică precum cea a lui Fundoianu. Iată încă o categorie în care Blaga și Fundoianu se plasează la poli opuși.

In planul poeziei mitologice, terenul comun de confruntare este tematica biblică, recurentă în poeticile celor doi, oferind diferențe simptomatice la analiză. Fundoianu va folosi, cu mici excepții, Vechiul Testament (în poeme precum Ultima verba. Cântarea lui Samson, Psalmul leprosului, Monologul lui Baltazar și Psalmul lui Adam.) în lirica sa, iar Blaga în preponderență operează cu Noul Testament (Ioan se sfasssie in pustie, Lumină din Lumină, Oaspeți nepoftiți etc.). În poemul Seară mistică autorul Priveliștilor se arată neîncrezător în valorile pozitive ale misterului. Ba chiar în mai multe poezii din unicul său volum, Fundoianu ironizează metafizicul, practică desacralizarea și demitizarea, adică se plasează, firește, la polul opus față de Blaga. Spre surprinderea noastră am observat că, în ciclurile veterotestamentare, din punctul de vedere amintit mai sus, Fundoianu s-a menținut pe o treaptă mai înaltă a comunicării cu transcendentul, rămânând fidel imaginarului și misticii iudaice, în timp ce Blaga intră în un din ultimele sale etape de creație în acea „trans-descendență” (în poeme precum Lumină din lumină, Colindă, Oaspeți nepoftiți, Ciocârlia) consecință a sofianicului și a influențelor culturii populare autohtone. Colindă este poate cel mai reprezentativ poem pentru această direcție în lirica blagiană. În evoluția discursului poetic la Blaga, după tristețea metafizică suntem martori la „clasicizarea” poetului. Clasicizarea nu înseamnă altceva pentru poezia blagiană decât folclorizare, anume îmblânzire formală și a imaginarului conform poeziei populare mitice românești. Poemul menționat mai sus funcționează după 
metrica colindului propriu-zis. În ceea ce privește transfigurarea biblică remarcăm, în primul rând, faptul că toposul nașterii nu este Betleemul biblic ci Viflaimul folcloric: „c-a născut la Vifleim,/n-are scutece de in”. Contaminarea arhaică se petrece și la nivelul imaginarului prin motive ca: opaiț, nănașă, in, lumânare de său etc. Efectul acestei domesticiri nu este altul decât diminuarea miracolului. Să practice Blaga, la fel ca Fundoianu, demitizarea? Pe scurt, în poezia cu tematică biblică, Fundoianu este mai metafizic decât poetul metafizic prin excelență: „de parcă ești în orice palmier,/ de parcă-n orice flacără ești, Doamne!” (Psalmul leprosului) sau „și-n sângele-mi fierbinte, ca un torent de lavă,/ zbucnea suavă,/ imperioasă verva strămoșului Adam.” (Ultima Verba). Considerăm important să accentuăm faptul că nu doar peisajul (levantin-iudaic pentru Fundoianu și mioritic pentru poetul din Lancrăm) este marea diferență dintre Blaga și Fundoianu în ceea ce privește mitologicul (dar și alte aspecte ale poeziilor celor doi) ci și spațiul-matrice în sine, cu tot bagajul inconștient cu care acesta se desfășoară în creația exponenților.

Departe de a fi epuizat în demersul comparativ diferențele dintre formele de metabolizare a curentului de proveniență germană în contextul cultural românesc, se poate observa însă și din acest stadiu un antagonism între principalii exponenți ai expresionismului în poezia românească, Lucian Blaga și Benjamin Fundoianu. În diferite arii cheie din estetica expresionismului, poeții vizați se plasează la poli opuși. Problematicile care au putut face posibilă confruntarea au fost selectate în așa fel încât să acopere arealuri importante și întinse din opera lirică a poeților vizați, în același timp înscriindu-se în principalele trăsături ale esteticii curentului german: teritorialitatea expresionistă - relația eului creator cu natura, primordialul, satul sau orașul; categoria apocalipticului - un capitol fundamental care particularizează expresionismul în contextul primei jumătăți a secolului trecut și, în final, felul în care poeții utilizează metafizicul, o categorie care a făcut posibilă împământenirea curentului în solul cultural românesc. În teritorialitatea expresionistă, am identificat atitudinile exodic și odiseic de partea lui Fundoianu, respectiv a lui Blaga, față de mediul natal. Pe lângă această dihotomie, notăm că Blaga și Fundoianu acuză spațiul orașului, respectiv al târgului pentru opoziția față de forțele naturii, doar că primul găsește soluția ontologică în lumea satului, iar al doilea în exodul înspre spații urbane și mai mari. În ceea ce privește categoria apocalipticului, dacă la Blaga apocalipticul se manifestă vertical pe scara transcendenței, la Fundoianu apocalipticul este orizontal. Cele două tipuri de apocaliptic pe care le-am identificat pentru fiecare 
dintre cei doi sunt apocalipsul teluric și cel agrest, în timp ce la Blaga descoperim apocalipsul celest și cel urban. În ceea ce privește problematica metafizică, a fost aleasă poezia mitologică drept teren de comparație, în speță poezia cu tematică biblică, unde matricea stilistică diferă pentru Fundoianu și Blaga, fapt ce va manifesta reflexii atât asupra imaginarului cât și asupra comunicării cu transcendentul. Așadar, în unele situații Fundoianu, care în Priveliști se dovedește un demitizator, în poeziile veterotestamentare relevă o covârșitoare prezență a metafizicului. In timp ce în cazul blagian, în poeziile cu tematică biblică metafizicul „coboară” sau eul resimte o destrămare a acestuia, drept consecință a pierderii contactului cu Marele Tot. 


\section{Bibliografie:}

SURSE PRIMARE:

Blaga, Lucian, Opera Poetică, Ediție îngrijită de George Gană și Dorli Blaga, Prefață de George Gană, București, Editura Humanitas, 2010. Fundoianu, Benjamin, Opere I - Poezia antumă, Ediție critică de Paul Daniel, George Zarafu și Mircea Martin, Cuvânt-înainte și prefață de Mircea Martin, Postfață de Ion Pop, Cronologia vieții și a operei și sinopsis al receptării de Roxana Sorescu, București, Editura Art, 2011.

\section{SURSE SECUNDARE}

Aderca, Felix, Mărturia unei generații, București, Editura EPL, 1967.

Blaga, Lucian, Ceasornicul de nisip, ediție îngrijită, prefațată și bibliografie de Mircea Popa, Cluj-Napoca, Editura Dacia, 1973.

Blaga, Lucian, Trilogia Culturii, București, Editura Humanitas, 2018.

Crohmălniceanu, Ovid. S., Literatura Română și Expresionismul, București, Editura Eminescu, 1971.

Fundoianu, Benjamin, Imagini și Cărți, Ediție de Vasile Teodorescu, Studiu introductiv de Mircea Martin, Traducere de Sorin Mărculescu, București, Editura Minerva, 1980.

Grigorescu, Dan, Istoria unei generații pierdute: Expresioniştii, București, Editura Eminescu, 1980.

Mariș, Ioan, Expresionismul în poezia și teatrul lui L. Blaga, Cluj-Napoca, 1996.

Martin, Mircea, Introducere în opera lui B. Fundoianu, București, Editura Minerva, 1984.

Manolescu, Nicolae, Despre Poezie, București, Editura Cartea Românească, 1987.

Pop, Ion, Lucian Blaga. Universul liric, Pitești, Editura Paralela 45, 1999. 